\title{
Social Acceptance of Students with Special Needs from Peer Viewpoint
}

\author{
Özlem Dağlı Gökbulut ${ }^{1}$, Burak Gökbulut ${ }^{2 *}$, Mustafa Yeniasır ${ }^{3}$ \\ ${ }^{1}$ Expert Special Education Teacher, Ministry of National Education, Nicosia, N. CYPRUS \\ ${ }^{2}$ Near East University, Faculty of Art and Science, Department of Turkish Language and Literature, Nicosia, N. CYPRUS \\ ${ }^{3}$ Near East University, Atatürk Faculty of Education, Department of Turkish Language Teaching, Nicosia, N. CYPRUS
}

Received 16 May 2017 • Revised 11 September 2017 • Accepted 8 October 2017

\begin{abstract}
Individuals with special needs have such rights as benefiting from health services and obtaining an education which is consistent with their abilities. As long as they can use these rights effectively like other individuals do, they are satisfied, active and productive in their social lives. Individuals with special needs who were ignored and neglected for centuries became socially accepted after social values began to change in a positive direction. This positive change was mostly felt in the field of education. The purpose of this study is to display the social acceptance level of students with special needs by normal peers in inclusive classes in TRNC (Turkish Republic of Northern Cyprus). According to the findings, female participant students show more positive social acceptance towards inclusive students compared to male students, and it was found out that social acceptance level does not show any difference based on age of the participants.
\end{abstract}

Keywords: peer views, Northern Cyprus, student, individuals with special needs, social acceptance, social acceptance

\section{INTRODUCTION}

Individuals in the society naturally have different characteristics from each other. Such differences are also reflected to their education lives, as a result of which education environments should be regulated taking this fact into consideration. As known, students with special needs have to benefit from equality of opportunities so that they can maintain their independent living skills in the society. In recent years, individuals with special needs are educated in the same environment with their peers, as the term "inclusive class" indicates, which is a widely adopted method.

It was noticed that students with special needs who are educated at separate schools in a boarding or nonboarding model are deprived from their rights to actively participate in social life within the process. Since 1970s, legislations have been made to allow for them to be educated with their normal peers in the same environment. Positive reflections of these legislations was effective in the adoption of inclusive education for students with special needs today.

Inclusive education aims at providing supporting services that help increase the independent living qualities of children with special needs and ensuring that they are educated in the same environment with their normal peers, acquire academic and social success through mutual interaction, and benefit from the opportunity of being an effective and productive member of the society (Kırcaali and İftar 1998; Akçamete and Ceber 1999; Sucuoğlu, 2006).

It is stated that thanks to the interactions and sharing they experience with their peers, students with special needs can establish healthy communication, effectively use their social role-modelling and communication skills, learn faster, as a result of which improve their self-control and self-esteem (Wu et al. 2008) 


\section{Contribution of this paper to the literature}

- Social inclusion of students with special needs is one of the key areas in inclusive education. Children in this paper gain role models with social personality roles by sharing the same physical media with their normal peers.

- One of the fundamental keys which ensure success for inclusion application is social acceptance by peers. The attitudes, prejudices and beliefs of peers without inabilities towards their peers with special needs is seen as an essential factor in their acceptance as friends of students with special needs.

- It is believed that this study will guide the educationists in the creation of the mentioned classrooms and educational programs.

It is also known that in addition to students with special needs, their normal peers are also positively affected by inclusive education and obtain certain acquisitions. For example the teacher presents the objectives of the class by making adaptations in teaching methods and materials which provides benefits for both types of students. It is known that the self-confidence and academic success of both types of students increases and normally developing students receive higher or the same scores from success tests compared to their peers who do not attend such a program (Sucuoğlu 2006).

It is argued that due to the intense interaction that students with special needs have with their normal peers, their sense of belonging to this group increases. In this case, class teachers have to plan activities and actions in inclusive classes which will facilitate acceptance of students with special needs by their peers and improve their friendship relations (Sucuoğlu 2006). Metin (1992) claims that when inclusive environments are well-planned, it will facilitate easy and intense interaction between normal peers and students with special needs who are especially at small ages, as a result of which social acceptance behaviour can be acquired at early ages.

In cases where social acceptance is low or non-existent, it is observed that children with special needs feel themselves lonely and valueless, their self-esteem and academic success worsens, and the low academic performance is expressed in such behaviours as aversion and disobedience (Sucuoğlu 2006; Demir Şad 2007; Ergüden 2008).

\section{Purpose}

The purpose of this study is to determine the social acceptance level of inclusive students with special needs by their normal peers in inclusive classes in TRNC.

\section{Research Model}

The purpose of the study is to determine the attitudes and behaviours of normally developing students in third, fourth and fifth grades of elementary schools in Turkish Republic of Northern Cyprus, thus, descriptive survey method was used. "Survey method consists of surveying activities on a universe consisting of multiple elements or a group, example or sample taken from the universe in order to reach a general judgment on the universe" (Karasar 2011, p. 79).

\section{Sample of the Model}

The universe of the research consists of In 2016-2017 academic year, the students at third, fourth and fifth grades of elementary schools who are between the ages of 8 and 10 in Nicosia, Kyrenia, Famagusta, Güzelyurt and İskele regions of Turkish Republic of Northern Cyprus with simple random sampling method.

The sample of the research consists of 595 students chosen with simple random model in relevant grade and age interval.

\section{Data Collection Tools}

Data collection tools used in this study consists of two parts. In the first part, the Personal Information Form developed by the researcher which asks the age and gender data of the participants is used; in the second part, Social Acceptance Scale which was developed by Siperstein (1980) and adapted to Turkish by Civelek in 1990 is employed. The questionnaire form used as data collection tool in the study was applied in the spring semester of 2016 through personal interview technique. 
Table 1. Definitive statistics as regards the answers given by students to social acceptance scale

\begin{tabular}{|c|c|c|}
\hline & $\overline{\boldsymbol{X}}$ & $\mathbf{s}$ \\
\hline I would tell him the homework when he missed the class. & 4.73 & 0.77 \\
\hline I would stand by him in the queue. & 4.26 & 1.13 \\
\hline I would play with him even after the school. & 4.02 & 1.28 \\
\hline I would lend him my pen or pencil. & 4.68 & 0.87 \\
\hline I would help him solve maths problems. & 4.38 & 1.13 \\
\hline I would protect him if other children mocked him. & 4.76 & 0.73 \\
\hline I would speak to him in free time in the classroom. & 4.11 & 1.27 \\
\hline I would invite him home. & 4.07 & 1.28 \\
\hline I would sit beside him in the classroom. & 3.95 & 1.32 \\
\hline I would play with him at school in free times. & 4.34 & 1.12 \\
\hline I would share with him a secret which only a few children knew in the class. & 3.36 & 1.63 \\
\hline I would approach him and say "hello". & 4.63 & 0.92 \\
\hline I would share my lunch with him. & 4.15 & 1.29 \\
\hline I would sit beside him at school trips. & 3.96 & 1.32 \\
\hline I would sometimes call him from home. & 3.68 & 1.49 \\
\hline I would stand by him even when he did wrong things. & 3.14 & 1.64 \\
\hline I would tell him about myself (I would mention myself) & 4.25 & 1.18 \\
\hline I would help him in group class projects. & 4.40 & 1.08 \\
\hline I would praise him in areas where he is successful. & 4.16 & 1.33 \\
\hline I would meet him with my friends. & 4.49 & 1.06 \\
\hline When we are playing peer games, I would choose him as my peer. & 3.72 & 1.42 \\
\hline I would tell him things about myself that I did not tell anyone before. & 3.30 & 1.59 \\
\hline Social acceptance scale - General & 4.11 & 0.68 \\
\hline
\end{tabular}

\section{Analysis and Interpretation of the Data}

Statistical Package for the Social Sciences (SPSS) 20.0 for Windows Evolution version was used in the statistical analysis of data.

\section{FINDINGS}

The mean and standard deviation values as regards the answers given to the expressions in social acceptance scale by students covered by the research are given in Table 1.

It is found out that students received scores above the mean value of 4.20 from the following expressions in social acceptance scale: "I would tell him the homework when he missed the class", "I would stand by him in the queue", "I would lend him my pen or pencil", "I would help him solve maths problems", "I would protect him if other children mocked him", "I would play with him at school in free times", "I would approach him and say "hello"“, "I would tell him about myself (I would mention myself)", "would help him in group class projects", and "I would meet him with my friends". As most of the students answered "yes" to these expressions, their opinions about these expressions are usually positive.

It is found out that students received scores between 3.40 and 4.19 on average from the following expressions in social acceptance scale: "I would play with him even after the school", "I would invite him home", "I would share my lunch with him", "I would sit beside him at school trips", "I would sometimes call him from home", "I would praise him in areas where he is successful", and "When we are playing peer games, I would choose him as my peer". It is found out that the students mostly gave positive answers to these expressions and marked the option "I think yes".

It is found out that students received scores between 3.14 and 3.39 on average from the following expressions in social acceptance scale: "I would share with him a secret which only a few children knew in the class", "I would stand by him even when he did wrong things" and "I would tell him things about myself that I did not tell anyone before". Students mostly answered to this question neither yes nor no.

Table 2 gives the definitive statistics obtained by students from social acceptance scale according to their gender and Table 3 gives Mann-Whitney $U$ test results as regards the comparison of scores obtained by students from the scale according to their gender. 
Gökbulut et al. / Social Acceptance of Students with Special Needs

Table 2. Definitive statistics as regards the social acceptance scale according to their gender

\begin{tabular}{cccccc}
\hline & $\mathbf{n}$ & $\overline{\boldsymbol{X}}$ & s & Min & Max \\
\hline Gender & & & & & \\
\hline Female & 300 & 93.57 & 13.20 & 34 & 110 \\
\hline Male & 295 & 87.51 & 15.96 & 22 & 110 \\
\hline
\end{tabular}

Table 3. Comparison of social acceptance scale scores of students according to their gender

\begin{tabular}{cccccc}
\hline & $\mathbf{n}$ & Rank mean & Rank total & U & P \\
\hline Gender & & & & & \\
\hline Female & 300 & 332.11 & 99632.50 & 34017.50 & $0.00^{*}$ \\
\hline Male & 295 & 263.31 & 77677.50 & & \\
\hline${ }^{*} \mathrm{p}<0.05$ & & & &
\end{tabular}

Table 4. Definitive statistics as regards the social acceptance scale according to their age

\begin{tabular}{cccccc}
\hline & $\mathbf{n}$ & $\overline{\boldsymbol{X}}$ & $\mathbf{s}$ & Min & Max \\
\hline Age & & & & & \\
\hline 8 years old & 51 & 91.16 & 14.01 & 61 & 110 \\
\hline 9 years old & 169 & 91.55 & 13.83 & 47 & 110 \\
\hline 10 years old & 259 & 91.59 & 13.77 & 34 & 110 \\
\hline 11 and more years old & 116 & 86.57 & 18.48 & 22 & 110 \\
\hline
\end{tabular}

Table 5. Comparison of social acceptance scores of students according to their age

\begin{tabular}{|c|c|c|c|c|c|}
\hline & $\mathbf{n}$ & Rank mean & $\mathrm{x}^{2}$ & sd & $\mathbf{P}$ \\
\hline \multicolumn{6}{|l|}{ Age } \\
\hline 8 years old & 51 & 302.45 & 5.37 & 3 & 0.15 \\
\hline 9 years old & 169 & 306.28 & & & \\
\hline 10 years old & 259 & 306.54 & & & \\
\hline 11 and more years old & 116 & 264.91 & & & \\
\hline
\end{tabular}

Table 6. Definitive statistics as regards the social acceptance scale according to number of siblings

\begin{tabular}{cccccc}
\hline & $\mathbf{n}$ & $\overline{\boldsymbol{X}}$ & $\mathbf{s}$ & Min & Max \\
\hline Number of siblings & & & & & \\
\hline None & 57 & 87.42 & 13.08 & 46 & 108 \\
\hline One sibling & 243 & 91.44 & 14.56 & 34 & 110 \\
\hline Two siblings & 163 & 91.88 & 14.32 & 47 & 110 \\
\hline Three siblings & 72 & 87.22 & 17.07 & 22 & 110 \\
\hline Four siblings and more & 60 & 90.45 & 16.38 & 22 & 110 \\
\hline
\end{tabular}

When Table 3 is examined, statistically significant difference is found between the scores obtained by students covered in the research from social acceptance scale according to their gender $(p<0.05)$. The mean value of the scores obtained by female students from social acceptance scale are found to be significantly higher compared to male students. In other words, female students gave more positive answers to the expressions in the scale compared to male students.

Definitive statistics as regards the social acceptance scale according to their age are given in Table 4 and Kruskal-Wallis Test results of social acceptance scores of students according to their age is given in Table 5.

It was found out that there was no statistically significant difference between social acceptance scores of students participated in the study according to their age $(p>0.05)$. It was identified that students gave similar answers to the expressions in social acceptance scale regardless of their age.

Table 6 gives the definitive statistics as regards the social acceptance scale according to number of siblings and Table 7 gives the Kruskal-Wallis test results as regards comparison of social acceptance scores of students according to number of siblings. 
Table 7. Comparison of social acceptance scores of students according to number of siblings

\begin{tabular}{|c|c|c|c|c|c|c|}
\hline & $\mathbf{n}$ & Rank mean & $\mathrm{X}^{2}$ & sd & $\mathbf{p}$ & $\mathbf{U}$ \\
\hline Number of siblings & & & & & & \\
\hline None & 57 & 248.40 & 9.84 & 4 & $0.04^{*}$ & \\
\hline One sibling & 243 & 308.80 & & & & $1-2$ \\
\hline Two siblings & 163 & 313.55 & & & & $1-3$ \\
\hline Three siblings & 72 & 264.17 & & & & \\
\hline Four siblings and more & 60 & 299.73 & & & & \\
\hline
\end{tabular}

Table 8. Definitive statistics as regards the social acceptance scale according to their grade

\begin{tabular}{cccccc}
\hline & $\mathbf{n}$ & $\overline{\boldsymbol{X}}$ & s & Min & Max \\
\hline Grade & & & & & \\
\hline $3^{\text {rd }}$ grade & 194 & 91.42 & 14.19 & 54 & 110 \\
\hline $4^{\text {th }}$ grade & 185 & 91.19 & 14.64 & 41 & 110 \\
\hline $5^{\text {th }}$ grade & 216 & 89.26 & 15.79 & 22 & 110 \\
\hline
\end{tabular}

Table 9. Comparison of social acceptance scores of students according to their grade

\begin{tabular}{cccccc}
\hline & $\mathbf{n}$ & Rank mean & $\mathbf{X}^{\mathbf{2}}$ & sd & P \\
\hline Grade & & & & & \\
\hline $3^{\text {rd }}$ grade & 194 & 306.52 & 2.20 & 2 & 0,33 \\
\hline $4^{\text {th }}$ grade & 185 & 305.19 & & & \\
\hline $5^{\text {th }}$ grade & 216 & 284.19 & & \\
\hline
\end{tabular}

Table 10. Definitive statistics as regards the social acceptance scale according to the education status of mother

\begin{tabular}{cccccc}
\hline & $\mathbf{n}$ & $\overline{\boldsymbol{X}}$ & $\mathbf{s}$ & Min & Max \\
\hline Education status of the mother & & & & & \\
\hline Illiterate & 51 & 89.08 & 16.09 & 41 & 110 \\
\hline Elementary school & 168 & 90.76 & 15.25 & 22 & 110 \\
\hline Secondary school & 101 & 91.70 & 16.29 & 22 & 110 \\
\hline High school & 160 & 91.12 & 13.75 & 34 & 110 \\
\hline Undergraduate and graduate degree & 115 & 89.17 & 14.39 & 47 & 110 \\
\hline
\end{tabular}

Table 11. Comparison of social acceptance scores of students according to the education status of mother

\begin{tabular}{|c|c|c|c|c|c|}
\hline & $\mathbf{n}$ & Rank mean & $\mathrm{x}^{2}$ & sd & $\mathbf{P}$ \\
\hline \multicolumn{6}{|l|}{ Education status of the mother } \\
\hline Illiterate & 51 & 284.15 & 3.65 & 4 & 0,46 \\
\hline Elementary school & 168 & 301.60 & & & \\
\hline Secondary school & 101 & 319.20 & & & \\
\hline High school & 160 & 300.19 & & & \\
\hline Undergraduate and graduate degree & 115 & 277.22 & & & \\
\hline
\end{tabular}

When the Kruskal-Wallis test results in Table 7 are examined, it can be seen that there is statistically significant difference between social acceptance scores of students covered in the study according to the number of siblings $(\mathrm{p}<0.05)$. This difference is caused by the students with no siblings and students with one and two siblings. It is found out that students with no siblings received lower scores from the scale compared to students with one or two siblings.

Table 8 gives the definitive statistics as regards the social acceptance scale according to their grade and Table 9 gives the Kruskal-Wallis test results as regards comparison of social acceptance scores of students according to their grade.

It has been found out that there is no statistically significant difference between social acceptance scores of students covered in the study according to their grades $(\mathrm{p}>0.05) .3^{\text {rd }}$ grade, $4^{\text {th }}$ grade and $5^{\text {th }}$ grade students gave similar answers to the expressions in social acceptance scale.

Definitive statistics as regards the social acceptance scale according to the education status of the mothers of students covered in the study and Kruskal-Wallis test results as regards comparison of scale scores are given in Tables 10 and 11, respectively. 
Table 12. Definitive statistics as regards the social acceptance scale according to education status of father

\begin{tabular}{cccccc}
\hline & $\mathbf{n}$ & $\overline{\boldsymbol{X}}$ & $\mathbf{s}$ & Min & Max \\
\hline Education status of the father & & & & & \\
\hline Illiterate & 18 & 86.28 & 17.28 & 47 & 110 \\
\hline Elementary school & 112 & 91.34 & 15.34 & 22 & 110 \\
\hline Secondary school & 122 & 92.84 & 15.17 & 22 & 110 \\
\hline High school & 187 & 91.07 & 14.68 & 34 & 110 \\
\hline Undergraduate and graduate degree & 156 & 88.12 & 14.22 & 47 & 110 \\
\hline
\end{tabular}

Table 13. Comparison of social acceptance scores of students according to education status of father

\begin{tabular}{|c|c|c|c|c|c|c|}
\hline & $\mathbf{n}$ & Rank mean & $\mathbf{X}^{2}$ & sd & $\mathbf{P}$ & $\mathbf{U}$ \\
\hline \multicolumn{7}{|l|}{ Education status of the father } \\
\hline Illiterate & 18 & 255.22 & 12.66 & 4 & $0.01^{*}$ & $2-5$ \\
\hline Elementary school & 112 & 309.87 & & & & $3-5$ \\
\hline Secondary school & 122 & 329.52 & & & & $4-5$ \\
\hline High school & 187 & 304.08 & & & & \\
\hline Undergraduate and graduate degree & 156 & 262.47 & & & & \\
\hline
\end{tabular}

Table 14. Definitive statistics as regards the social acceptance scale according to having a sibling with disability

\begin{tabular}{cccccc} 
& $\mathbf{N}$ & $\overline{\boldsymbol{X}}$ & $\mathbf{s}$ & $\boldsymbol{M}$ & $\mathbf{M}$ \\
\hline Siblings with disability & & & & & \\
\hline Yes & 28 & 92.68 & 15.04 & 54 & 110 \\
\hline No & 567 & 90.46 & 14.94 & 22 & 110 \\
\hline
\end{tabular}

Table 15. Comparison of social acceptance scores of students according to having a sibling with disability

\begin{tabular}{cccccc}
\hline & $\mathbf{n}$ & Rank mean & Rank total & U & P \\
\hline Siblings with disability & & & & & \\
\hline Yes & 28 & 327.16 & 9160.50 & 7121.50 & 0.36 \\
\hline No & 567 & 296.56 & 168149.50 & & \\
\hline
\end{tabular}

When the test results in Table $\mathbf{1 1}$ are examined, it has been found out that there is no statistically significant difference between social acceptance scores of students covered in the study according to the education status of their mother $(\mathrm{p}>0,05)$.

Definitive statistics as regards the social acceptance scale according to the education status of the fathers of students covered in the study and Kruskal-Wallis test results as regards comparison of scale scores are given in Tables 12 and 13, respectively.

When the Kruskal-Wallis test results are examined, it has been found out that there is statistically significant difference between social acceptance scores of students covered in the study according to the education status of their mother $(p<0.05)$. Students whose fathers have undergraduate and graduate degrees received lower social acceptance scores compared to students whose fathers have elementary, secondary and high school degrees.

Table 14 gives the definitive statistics as regards the social acceptance scale according to having a sibling with disability and Table 15 gives the Mann-Whitney $U$ test results as regards the comparison of scores obtained from the scale by students according to having a sibling with disability.

When Table 15 is examined, it was found out that there is no statistically significant difference between social acceptance scores of students covered in the study according to them having a sibling with disability $(p>0,05)$. There is no difference between the scores of students with and without a sibling with disability.

Tables 16 and 17 give the definitive statistics as regards the social acceptance scale according to having a friend with disability and Mann-Whitney $U$ test results as regards the comparison of scores obtained from the scale by students according to having a friend with disability, respectively.

It was found out that there is statistically significant difference between the scores obtained by students from social acceptance scale according to having a friend with disability $(\mathrm{p}<0.05)$. Students with a friend with disability received higher scores from the scale compared to students without no friends with disability. In other words, students with disabled friends gave more positive answers to the expressions in the scale compared to the students with no friends with disabilities. 
Table 16. Definitive statistics as regards the social acceptance scale according to having a friend with disability

\begin{tabular}{ccccccc}
\hline & $\mathbf{n}$ & $\overline{\boldsymbol{X}}$ & $\mathbf{s}$ & $\mathbf{M i n}$ & & \\
\hline Friends with disability & & & & & \\
\hline Yes & 206 & 92.97 & 13.63 & 46 & 110 \\
\hline No & 389 & 89.29 & 15.45 & 22 & 110 \\
\hline
\end{tabular}

Table 17. Comparison of social acceptance scores of students according to having a friend with disability

\begin{tabular}{ccccc}
\hline & n & Rank mean & Rank total & U \\
\hline Friends with disability & & & & \\
\hline Yes & 206 & 324.50 & 66846.00 & 34609.00 \\
\hline${ }^{*} \mathrm{p}<0.05$ & No & 389 & 283.97 & $0.01^{*}$ \\
\hline
\end{tabular}

\section{CONCLUSION AND DISCUSSION}

According to the results of the study which examined the social acceptance of students with special needs by their peers in Turkish Republic of Northern Cyprus:

It has been observed that female students who participated in the study showed more positive social acceptance compared to male students. It is believed that this difference is caused by the fact that girls are more emotional compared to boys. When the results of the study are compared to other studies from this perspective, De Boer et al. (2012) conducted a study in 20 different countries on the basis of attitudes of peers towards students with special needs examining publications in a time span of 13 years and found out that female students showed more positive attitude compared to male students. These findings are similar to those of our study, whereas Kargin and Baydik (2002) and Ayral et al. (2015) concluded that gender variable of peers did not have any impact on the social acceptance of inclusive students.

Based on the finding that there is no difference in social acceptance by participants according to their age, it can be claimed that children accepted their friends with special needs regardless of their age. The findings in Ayral at al. (2015) support the findings of our sturdy whereas Swaim and Morgan (2001) claim that, different from our findings, the age factor is effective on attitudes and it became positive at lower ages.

Our research found that the grade of peers is not an effective factor on social acceptance. This shows that participant students are not at a level to develop judgments with definite borders in terms of their age and grade, and the borders of their attitude and social acceptance are permeable.

It is seen that the participant peers who have a disable friend show more positive social acceptance compared to the peers with no disabled friends. This finding indicates that creating more frequent interaction between normally developing peer sand children with special needs can affect the social and personal development of children in further ages positively.

It is also witnessed that peers with no siblings have more negative social acceptance values compared to students with siblings. Based on this finding, it can be claimed that children with no siblings can be more egocentric and less empathic compared to children with siblings, and as they did not know how to share and develop friendship, they can be more distant to their peers with special needs.

The finding that education status of mothers is not effective on the social acceptance by peers indicates that, as women are more empathic and emotional compared to men, regardless of their educations status and workload level, they can spare more time to their children help them develop didactic and empathic skills. Nevertheless, it is seen that peers whose fathers have undergraduate or graduate degree have more negative social acceptance levels. This result indicates that fathers with high education status spare ore time to their careers and cannot reserve enough time for their children.

In conclusion, this research we conducted on the students in Turkish Republic of Northern Cyprus, it is seen that the peers who participated in our study have generally positive social acceptance attitudes towards inclusive students.

\section{REFERENCES}

Akçamete, G., \& Ceber, H. (1999). Kaynaştırılmış sınıflardaki işitme engelli ve işiten öğrencilerin sosyometrik statülerinin karşılaştırmalı olarak incelenmesi. (Comparative examination the socio-metric statuses of students with and without hearing impairs in inclusive classrooms). Ankara University Faculty of Education Sciences Journal of Special, 2(03). 
Ayral, M., Özcan, Ş., Can, R., Ünlü, A., Bedel, H., Şengün, G., ... \& Çağlar, K. (2015). Normal Gelişim Gösteren Öğrencilerin Özel Gereksinimli Öğrencilere Bakışını Etkileyen Etkenler. Abant İzzet Baysal Üniversitesi Eğitim Fakültesi Dergisi, 15.

Civelek, A. H. (1990). Ĕ̆itilebilir zihinsel özürlü çocuklarnn sosyal kabul görmelerinde bütünleştirmenin etkileri. (The impact of inclusion on social acceptance of trainable mental retarded children) (Master's thesis). Ankara: Ankara Üniversitesi.

de Boer, A., Pijl, S. J., \& Minnaert, A. (2012). Students' attitudes towards peers with disabilities: A review of the literature. International Journal of Disability, Development and Education, 59(4), 379-392.

Ergüden, A. D. (2008). Sosyal Dışlanma açısından bedensel engelli bireylerin yaşantılarının incelenmesi. (An examination of the lives of individuals with physical handicaps from the point of social exclusion) (Unpublished master's thesis). Ankara: Hacettepe University.

Karasar, N. (2011). Bilimsel araştırma yöntemi (Scientific research method). Nobel Publications.

Kargın, T., \& Baydık, B. (2002). Kaynaştırma ortamındaki işiten öğrencilerin işitme engelli akranlarına yönelik tutumlarının çeşitli değişkenler açısından incelenmesi. (An examination of the attitude of students without hearing disabilities towards students with hearing disabilities in inclusive environments based on various variables). Ankara University Faculty of Education Sciences Journal of Special Education, 3(02).

Kırcaali-İftar, G. (1998). Kaynaştırma ve destek özel eğitim hizmetleri. (Inclusion and support special education services). Özel eğitim (pp. 17-26). Eskişehir: Anadolu Üniversitesi Açık Öğretim Fakültesi İlköğretim Öğretmenliği Lisans Tamamlama Programı.

Metin, N. (1992). Okul öncesi dönemde özürlü çocuklar için kaynaştırma programları. (Inclusion programs for students with disabilities in pre-school period). Ankara University Faculty of Education Sciences Journal of Special Education, 1(02).

Sucuoğlu, B. (2006). Etkili kaynaştırma uygulamaları (Effective Inclusion Applications). Ankara: Ekinoks Yayınevi.

Swaim, K. F., \& Morgan, S. B. (2001). Children's attitudes and behavioral intentions toward a peer with autistic behaviors: Does a brief educational intervention have an effect? Journal of autism and developmental disorders, 31(2), 195-205.

Şad, E. D. (2007). Akranları tarafindan reddedilen ve kabul edilen ilköğretim 2. kademe öğrencilerinin özsaygl, sosyal beceri, davranıs problemleri ve okul başarılarının karşılaştırılması. (Comparison of self-respect, social skill, behaviour problems and school achievements of secondary school students who are rejected and accepted by their peers) (Master's thesis). Ankara: Ankara University.

Wu, T. W., Ashman, A., \& Kim, Y. W. (2008). Education reforms in special education. Reform, inclusion $\mathcal{E}$ teacher education: Towards a new era of special education in the Asia-Pacific Region, 12-29.

\section{http://www.ejmste.com}

